\title{
Yugoslavia
}

\author{
Sofya Zahova
}

\subsection{Introduction}

There were dynamic processes in terms of ethno-cultural and political developments in interwar Yugoslavia. At that time, various undertakings, initiated by Roma informal and formal organisations, were taking place. These initiatives varied, in terms of activities, and included church services in Romani language as well as cultural clubs, community customs and commemorations, which were signs of Roma's emancipation and representation. The endeavours' overall goal was essentially the same: to unite, mobilise, and represent the Roma community as people equal to all others in the Yugoslav public space. The pioneering examples of Romani literature and publications during this period should be interpreted precisely in the framework of this general goal. They included publications in Romani language such as The Gospel of Luke and Romane gilja, a collection of Roma songs' texts, both produced by Rade Uhlik, as well as original literature in various prose genre pieces, authored by Svetozar Simić, the most prominent activist of the time.

After a short overview of the Yugoslav historical context, and a discussion of Roma activism in the first parts of the chapter, the discussion moves to the first publications that targeted Roma audiences. Romano lil (Roma paper, in Romani language) / Ciganske novine (Gypsy newspaper, in Serbian), initiated and edited by Simić, was the first and only Roma-led journalistic endeavour in interwar Yugoslavia. According to the editor, "our newspaper has been set up in order to write about Gypsies, but understandably for Gypsies." (Симић 1935a:1) The focus of the chapter is a comprehensive analysis of the Romano lil newspaper in several sections, dedicated respectively to its production, content overview and narratives. Additionally, Simić's unpublished literature pieces are discussed.

With reference to Romano lil's texts, the chapter focuses on how Simić and his collaborators conveyed their visions about the Roma emancipation in literature form. Roma are presented as a people united by a common culture and historical memory, thus equal to the other people of the Yugoslav Kingdom, who needed to be included in all processes of the social and public sphere. Along with this, in many of the texts the two dimensions of belonging - to the Roma community and to the Yugoslav/Serbian society - were publicly expressed. 
The Kingdom of Serbs, Croats and Slovenes was created at the end of the First World War as a twelve-million citizen territory, to unite the former lands of the Kingdom of Serbia, the Kingdom of Montenegro, and some territories of the Austro-Hungarian Empire (Vojvodina and the shortly existing provisional state of Slovenes, Croats and Serbs) under the rule of the Karadjordjević dynasty (Banac 1988:132-140). In 1929, the kingdom was renamed the Kingdom of Yugoslavia. For the purposes or simplification, the term Yugoslavia will be used hereafter for the name of the kingdom throughout the interwar period, between 1918-1941.

The overall number of Roma/Gypsies in interwar Yugoslavia is uncertain. According to Tatomir Vukanović the number of Gypsies in the Serbian territories of the Kingdom of Yugoslavia in 1921 was 34,919 (Вукановић 1983:121). The highest estimate in studies reaches 250,00о (Djurić 1987:67) and over 30о,ооо (Ацковић 20о9:61), which was a rather insignificant share of the kingdom's population. As far as the individual rights of the Roma, it can be affirmed that all Roma individuals with citizenship had the same rights as all other citizens of the state, and, as far as sedentary groups on Serbian territories were concerned, they had such rights since the Serbian independence in the nineteenth century (Стојанчевић 1992).

In the general atmosphere of studying all ethnic communities in Yugoslav territories, during the interwar period, scholars were researching the culture and language of the Roma/Gypsies. Tihomir Djordjević [Gjorgjević], a Serbian leading ethnographer, whose PhD thesis about Gypsies was defended in Munich (Gjordjević 1903, 1906), continued to publish the results of his research in both Yugoslavia (Ђорђевић 19o9, 1932, 1933a, 1933b) and abroad (Gjorgjević 1907a, 1907b). Some periodicals, such as Zbornik za narodni život i običaje Južnih Slavena (Review on Folk Life and Customs of the South Slavs), published in Croatia, developed ethnographic questionnaires for Gypsies, modelled according to the common pattern of the time, and appealed to the readers to implement them and send information, which was consequently published (Vojak 2004:210-211). Some local studies in the field of history and ethnography also included parts related to Gypsy groups in their territories (Hrvatska Enciklopedija 1942; Vojak 2010, 2017; Ђорђевић 1932, 1933а), and there were collectors of Romani words in amateur vocabularies. Among the groups of amateur researchers stands the name of Antun Medven, a Catholic priest from the eparchy of Križ, near Zagreb, who learned the Romani language, and in the 193os compiled a Romani grammar and Roma folklore collection with song texts and tales that is unpublished thus far and preserved in his archive (Vojak 2009:117-20; 2013:180).

Another scientist during this period was Aleksandar Petrović, a physician interested in Roma communities. He was an employee in the Institute of Hygiene in Belgrade who had done research among Roma, published articles in Yugoslav journals or as separate studies (Петровић 1937b) as well as in the Journal of the Gypsy Lore Society during the second half of the 193os. He corresponded with the leadership of the Gypsy Lore Society, sending 
materials, written and photographed, on various topics related to the Roma in Yugoslavia, their history, way of life, beliefs and culture (Petrović 1935, 1937).

Similar to other folk communities in the South Slavic territories, interest towards their own history and the need for publishing in their own language, also appeared among the Roma. Although Roma cultural, political and civic initiatives were not an object of measures on behalf of the state, such activities were not lacking. As Dragoljub Acković (2001, 2017а; Ацковић 200о) has argued, grassroots initiatives and self-organising efforts of Roma did exist, both formal and informal. There were several accomplishments led by Roma, e.g. a couple of organisations and the newspaper enterprise discussed here. Among these accomplishments were the First Serbian-Gypsy association (zadruga) for mutual support in sickness and death (Prva Srpsko-Ciganska zadruga za uzajmno pomaganje u bolesti $i$ smrti), active in the 1920 and 193os, that most probably was based on an earlier form of a community organisation. The organisation's goal was to provide its members with help and support in various situations. The second known organisation is the socalled Club of the Belgrade Serbian Gypsies (Klub beogradskih srpskih Cigana), and information about its activities, which were reported in the media, point to the fact that the Club claimed rights for political representation and participation in the decision-making bodies at the local and national level. More is known about the third organisation, The Association of Belgrade Gypsies Worshippers of "Bibija” (Tetkica) (Udruženje beogradskih Cigana svečara "Bibije" (Tetkice), established in 1935. According to the Association's Statute, its goals included raising the cultural level of all its members by establishing new and supporting already existing cultural and social institutions, accepting gifted kids and young people, with the aim of education and the study of crafts (Acković 2004, 2010; Marushiakova and Popov 2021a:18o-217). The fourth organisation, The Educational Club of the Yugoslav Gypsy Youth (Prosvetni klub jugoslovenske ciganske omladine), active shortly in the late 1930s, was presided over by Svetozar Simić (Николић 1939:10). There were also Roma local initiatives that were taking place in the cultural, social, religious and political life at the local level. Among the initiatives were the registration of Roma in political parties who stood for elections in the 1920s (Marushiakova and Popov 2021a: 218-235), the initiative for the building of the so-called 'Gypsy Church' after the First World War in Privlaka (today in Eastern Croatia) with donations from the Rom Čedomir Nikolić, where in 1938, in front of a Roma audience from the Vukovar-Srijem region, the newly translated Gospel of Luke (Uhlik 1938) was read (Acković 2014:205-208; Vojak 2013:184; Комски 1938). The emergence of the Gypsy church in the region of Eastern Croatia, could be explained by the importance of the religion as a marker of identity for the two major ethnic communities there - Catholic Coats and Orthodox Serbs. Although technically belonging to the Orthodox Serbian Church, the Gypsy church was conceptualised as a separate church to express the differentiation of the Roma community from all others. In Niš, Southern Serbia, in 1928, the Gypsy Singing Society Sloga (Accord) was established, and in 1932 the football club Gajret (Zeal) (Jašić 2001:25) was founded. According to local community memory, the football club was entirely comprised of Roma, although it was 
not officially stated that it had an ethnic character. In some Croatian territories Roma Catholics were also raising voices for inclusion in the state and religious institutions. For example, the Roma in Sveta Klara (now a neighbourhood of Zagreb) and nearby places in the region of Central Croatia, were requesting land from the authorities for agriculture (Vojak 2014:150, 171). The same community was part of the Catholic parish and a big Catholic sermon in the Romani language was organised for them on the day of St Juraj (known as George's Day of Spring) in 1940 (ibid.:180).

Thus, Roma initiatives in the cultural, social, religious and political life at the local level were numerous and were undoubtedly related to the differentiation of the Roma community, on the basis of their common Roma identity. It was thus logical that the goals and activities for equalisation to the other communities, and representation of the Roma people in the public life of Yugoslavia, were also extended to other public fields such as media and publishing.

\subsection{First Roma Publications}

The foundation of Romani literature in Yugoslavia, similar to most of the countries where Romani literature appeared, was related to folklore and religious publications. The first scholar, who encouraged the development of the identity of the Roma community, through Romani language books focusing on the Roma people as an audience, was Rade Uhlik (1899-1991).

Uhlik was born to a Bosnian Croat family, and since the interwar period actively collected oral traditions and studied the Romani Bosnian dialects, creating a Romani language dictionary and numerous collections that were later published, while some remain unpublished (Acković 2019). Uhlik was also the first to give credit to individual Roma for their authorship as narrators or creators of folklore. He purposefully addressed and identified Roma people as the audience of his publications, in his first collection of Roma songs, Romane gilja. Циганске песме, published by Vučen Štrbac publisher in Prijedor (Uhlik 1937). The book's Introduction, by Rade Uhlik, is of key importance in the perception of Roma as people who had their own written tradition, in unison with the ideas of contemporary and later Roma activism for emancipation through public representation and circulation of their own folklore, as well as their language and its diversity:

\section{BROTHER ROMA!}

Here, I created one Roma book and I distribute it all across the country, letting the beautiful Romani word be heard all around. It is high time to do that.

What do I want to do? People do not think about their black brothers! There are two hundred thousand Roma [in Yugoslavia], in the whole world they are ten times more. Thus, it is a shame that they don't read books! This is unfortunate for the Roma.

In these books there are circa a hundred poems and short poems, which I collected from many places. There could be words that you don't know, because the Roma don't speak the same way in different places. But you are going to understand what the meaning is. Roma 
have to know more of their words, in order to be able to speak more easily between each other. It was difficult for me to collect the poems.

The Romani language and Roma song must not disappear. That is why each Rom has to collect the Roma songs. Thus, I'm going to come to your place to put the songs on paper and to distribute them among the Roma. Not a single Rom has to pay for these books, I distribute them for free.

Roma!You have to read and to sing these songs and to preserve your language in this way. I know that this booklet comes out for your goodness. Therefore, until we meet l'd like to tell you:

$$
\text { Stay with God! }
$$

Whoever knows more songs, let him send them to me at this address:

RADE UHLIK, professor, Prijedor, Vrbaska banovina

(Uhlik 1937:n.p.)

Another unpublished manuscript of Uhlik from the interwar period, consists of Roma tales, collected during the 193 os from different locations in Bosnia (Uhlik 1940). Probably due to the situation in Yugoslavia, which was occupied in 1941 by Fascist forces, the manuscript was not published as the songs' textbook. Its title is Phirasavne paramiča andar o romano durutnipe (Funny stories/anecdotes from the Roma past), and the text is entirely in Romani language, addressing Roma, who should laugh, but not be laughed at:

Friends,

I made this book [for you to] laugh a bit. The life of Roma is very hard and poor. That is why sometimes they need their heart to become full of joy. Do not be ashamed and do not think that this is something like a joke with the Roma. These tales are not true ones, they are made up. I publish in this book the tales in the way they were told to me.

All the tales are in the Romani language, and not a single one has a Serbian word. That is why no one who is not Rom can understand the meaning of these tales and cannot make jokes with the Roma.

Hereby I send this book among you so that you can also learn to understand how the language was spoken in the by-gone days of the Roma life.

Rade Uhlik

Scholar

(Uhlik 1940:1-2)

Both introductory words given above were exclusively in Romani language as the two books were directed to a Roma audience. The readers had to be engaged and feel proud of their oral heritage finding place on the pages of a book "to travel to the whole land," as Uhlik points out. In an interview with the mainstream Pravda newspaper, shortly before publishing the Roma Songs collection, Uhlik said: "Among the Gypsies, similarly to other people, songs represent an expression of the peoples' soul.” (Курбеговић 1937:8)

Several of Uhlik's manuscripts address the Roma in this manner which is a clear message that Uhlik was promoting the idea of Roma oral heritage becoming written and developing the literature genre to become a representation of the Roma consciousness 
and Roma culture. Thus, Uhlik's publication of the interwar period and many other manuscripts of that time, can be considered Romani literature produced in Romani language and for a Roma audience, under the overall aim to preserve the folklore that presents the Roma folk-spirit and to subsequently establish Romani language tradition in writing form. Uhlik is considered the first Romani studies scholar in Yugoslavia, and rightfully called since the time of his early publications the "Gypsy Vuk Karadjić" (Петровић 1937b).

Uhlik translated O Devlikano lil e Sumnale Lukahtar (The Gospel of Luke) into Romani language (Bosnian Gurbet dialect), published by the British and Foreign Bible Society in Belgrade (1938). The text was actually circulating in Yugoslavia and was used by both Catholic and Orthodox services. The word about the Gypsy church seemed to spread quickly and in 1938 the priest Lazar Staminirović read in front of a Roma audience, from the Vukovar-Srijem region, in the Gypsy church of Vinkovci (see above), attracting Orthodox Roma who visited from other regions of Yugoslavia, Roma Catholics and also Croat Catholics, who were curious to listen to the unique Romani language service (Рајчевић 1938). Antun Medven, also used the religious translation in his Catholic services and also probably was preaching in the Romani language, himself being a Romani speaker, in 1940 (Vojak 2013:180). The religious texts were an expression of the need of the Roma community of all Christian denominations to be addressed in their own language, which would distinguish them from other communities. Furthermore, to address the needs of the Roma community, and reaffirm their identity, religious services were organised for the Roma in Romani language on their main holidays, such as the day of St George or Djurdjevdan (Комски 1938:9). There were also Belgrade Roma's own project for translation of Bible text (Николић 1939:10), which was not realised but was a clear signal of the idea that Roma should be engaged as main actors in these translations.

The activities of Rade Uhlik were a watershed moment in this process, as his religious texts' translations and the two books compiled by him in the interwar period $(1937,1940)$, were intended as publications for a Romani reading audience and were interrelated with the ideas for Roma emancipation through turning their linguistic and cultural heritage into written forms equal to all other people's traditions. It is thus not surprising to note that the Roma folklore collections of Rade Uhlik formed the foundation of Romani literature in Yugoslavia, becoming a source for publishing of Romani language reading materials as well as a literary model for Roma poetry and prose works for both Roma authors (Tahirović Sijerčić 2009a, 2009b, 2010), Roma researchers (Heinschink et al. 2006), and the general Yugoslav literary scene (Ухлик \& Радичевић 1957, 1982).

\subsection{Svetozar Simić and the Production of Romano Lil}

As shown above, there were numerous instances of Roma self-organisation, representation and emancipation led by Roma in Belgrade or other localities during the interwar 
period, but Svetozar Simić (1913-1979) was the only Roma personality whose activism was interrelated with literary and journalistic activities in the public field.

Born in 1913 to a Roma family, in a village near Arandjelovac in Central Serbia, Simíc moved to Belgrade after graduation from high school. He continued his studies in the Yugoslav capital, becoming a law student in 1935. In the 1930s, Simić co-authored with Aleksandar Petrović, three studies related to Roma groups, culture and customs - About the marriage among our Gypsies (Петровић \& Симић 1934а), About religion among our Gypsies (Петровић \& Симић 1934b), and Theft among Gypsies (Петровић \& Симић 1934 c). In the spring of 1935 Simić started as editor, publisher and main contributor Romano lil. Циганске новине, a monthly newspaper that was issued in three editions, March, April and May.

Later, in 1938-1939, Simić was the founder and president of the Educational Club of Yugoslav Gypsy Youth that existed shortly before the start of the Second World War (see above). Simić was in contact with the network of Roma activists and researchers of Roma culture throughout his life. He corresponded with Rade Uhlik. Simić also worked on Romani grammar and vocabulary, novel(s), as well as a memoir (Acković 2014:263406). A theatre play script on the topic of the Roma destiny during the Second World War, found in his archive, has been attributed to him, but in fact had been written by Spasoje Mitrović who probably wanted to consult with Simić about the script. Most of the materials are unpublished thus far, and part of them are kept in the Personal Archive of Dragoljub Acković (LADA, f. Svetozar Simić; Acković 2O2O.). The references below to unpublished literature works are from this archive.

According to the archive and bookkeeping documents of Romano lil newspaper, Svetozar Simić was the founder, editor-in-chief and manager of the paper. The headline contained information that the newspaper was edited by a team. The last page of each Romano lil issue indicated the managerial and editorial position of Simić: "Owner and editor in chief: Svetozar Simić, Jatagan mala III raw 24. Printed by M. Sibivkić - 9, Kralj Marko street." The newspaper was published on four pages, by a printing house in Belgrade. The publishing box does not contain information about the print run, but according to a review of the newspaper, published in 1936 in the Journal of the Gypsy Lore Society (JGLS) by Jopson, based on information provided by Aleksandar Petrović, the print run was 500 copies for the first two issues and 1000 copies for the third one (Jopson 1936:87).

It is, however, necessary that one particular misunderstanding concerning the newspaper be deconstructed and eliminated. According to the mentioned review of Romano lil in the JGLS, Aleksandar Petrović is reported as the person who founded and tried to maintain the newspaper, despite all obstacles, financial difficulties and obstructions:

The lone and heroic efforts of Dr. Alexander Petrović to found a Gypsy newspaper have an element of pathos. Difficulties which would have daunted all but a wholehearted enthusiast faced the project from the very start. Money had been undoing of an earlier attempt to form 
a Belgrade Gypsy Society (the Administrative Committee had contrived a neat get-away with the funds collected!), and money was destined to exercise a baneful influence on the newspaper plans also ... But, all joking aside, the paper does real credit to the enthusiasm of Dr. Petrović. (Jopson 1936:86-89)

Petrović was indeed one of the main contributors to the newspaper and, despite the fact that he was not explicitly mentioned in the newspaper's administrative records, he was a collaborator in Simićs endeavours and the materials written by him form a substantial part of the small newspaper. Nothing, however, points to the fact that Petrovic was the one who started or tried to maintain the endeavour. In fact, all preserved documents from the bookkeeping and archive of Romano lil - manuscripts, financial records, as well as the printed copies of the newspaper, attest undoubtedly that Svetozar Simić was the main figure behind its publishing. Furthermore, according to a comprehensive article in the genre of a portrait interview with Simić, published in one of the most influential daily newspapers in Yugoslavia, Vreme, the editorial office was set up in Simićs father's house in one of the Gypsy neighbourhoods of Belgrade (Митровић 1936:5). We may speculate why Petrović had misrepresented himself and had been further misrepresented in the JGLS publication as the editor and main agent behind Romano lil's publishing. In a letter dated May 12, 1935 to Scott Macfie, then JGLS Editor, Petrović sent two copies of the newspaper. In the accompanying letter he wrote:

I edit it and publish it together with a Gypsy student. But none of the Gypsies buy it. I had the idea to assemble as many as possible literate Gypsies around it, but it seems it won't be a success. I keep a diary of the history of the paper. All my experience in connection with it, will be a very good contribution to the study of the Gypsy psychology. (Petrović 1935, May 12)

What strikes one here is that the actual editor of the paper, and known to the Belgrade public, Svetozar Simić, is reduced to an anonymous "Gypsy student." Petrović, as author of a series of contributions on Serbian Gypsies in the JGLS (Third Series, Volume 14-19), and the main correspondent of the leadership of the Gypsy Lore Society in the interwar period, was an authority whose claims were accepted without doubt or need for verification. Also, it seems that Petrović viewed the whole process as a scientific experiment to contribute to the study of "Gypsy psychology" quite in unison with the racial discourse of the time. I agree with the opinion of Dragoljub Ackovic that this is a clear case of purposeful falsification (personal communication, December 7,2018 ). This pattern is linked to the historically affirmed practice of marginalisation and underestimation of Roma, not as active agents of their history and culture, but always needing to be led by nonRoma. The case of Petrović presenting himself as an editor and heroic entrepreneur in the letter, and the purposeful omission of Simić's name on the review of the newspaper, is not only an example of the diminishment of his own achievements, but also, a clear case of concealment of the facts and misrepresentation of the leading role of a Rom. 
Petrović was indeed a main contributor to the newspaper who authored major pieces in it (Петровић 1935a, 1935b, 1935c). Interestingly enough, when writing for Romano lil he had adopted a narrative of addressing the Roma community as if he was a member of the community itself, speaking of a collective by using the third person plural (we): "We the Gypsies love more our children than anything in the world" (Петровић 1935a:1), "We do not know if this celebration is related to an event from our peoples' history as we do not have a written history." (Петровић 1935c:3) As Romano lil's author, Petrović appropriated a position of a community member and Roma writer. This practice raises an interesting enquiry into the participation and collaboration of people of non-Roma ethnicity in Roma journalism and activism, which has been not a unique but rather a common pattern since the birth of Roma activism and writing. This pattern is something that is observed at present in the Roma movement, as well as in the field of Roma writing and publishing.

Thus, Petrović had a role as a member of the editorial team but, for the sake of historical accuracy, it should be noted that no archival records point to him as a founder, manager or editor of the newspaper. This role belonged to Svetozar Simić. Apart from the archival materials, the Belgrade Roma have preserved the memory of Simić and his publishing endeavours. Roma activists later looked at Svetozar Simić and Romano lil as a benchmark of Roma journalism and made an effort to revive the newspaper during the 196os and the 1970s (Берберски 1969:51). Noteworthy is that one of the first journals in Yugoslavia in the 1990s was named Romano lil and was edited by Dragoljub Acković.

The newspaper was written and published mainly in the Serbian language, but there was hardly a piece in which Romani language was not present. To flag Roma identity, the newspaper's name was in the Romani language and Romani was often used in phrases quoted in articles or when folklore texts were published. It is interesting to note that the Romani language name of the newspaper was written with Latin script, while the Serbian one was written with Cyrrilic. It was not unusual to publish in Latin script in interwar Yugoslavia as both Latin and Cyrillic script were officially used to write in the Serbo-Croatian since the establishment of the Kingdom in 1918. We can only guess what could be the reasons for choosing Latin script for the Romani language title of the newspaper as there is no explanation offered for this. Otherwise Simić published all Romani phrases and texts in Cyrrilic. We could suppose that the newspaper's team indeed targeted a wider audience even beyond the borders of Yugoslavia and the Latin scrip title might have been instrument in this demonstration of internationalism.

The choice of Serbian as the dominating and main language of the newspaper did not in any way diminish the value or the concept of Romano lil as a Roma media. On the one hand, the reason was conceptual - although it was directed primarily towards Roma audience, it was also aiming to address non-Roma readers and communicate to the public the strategic ideas of the editorial team. As a matter of fact, until today the dominant pattern of publishing Roma periodicals worldwide is the same: the print media titles are 
in the Romani language, while they are published primarily in the official language of the country, and usually having Romani language folklore and original fiction materials (Zahova 2019:354). The same goes for the prose genres written by Roma, as novels, memoirs, etc. From the point of view of Roma authors and editors, the reason for this is not that Roma authors or journalists are not fluent in their mother tongue, but that they generally also address non-Romani audiences with a strategy to (re)present a Roma reality and Roma narrative, very often in contrast to a stereotypical narrative dominating the public space. A more practical and less important reason in the case of the newspaper may have been the high illiteracy rate among Roma in any language in the interwar period, and in the case of those who had reading abilities, they had received their education primarily in the Serbian language.

The price of the newspaper was one Serbian dinar, which, according to the standard of the time, was the price of a daily newspaper. The editorial of the third issue discusses: "the financial side of our newspaper is very low. It has never been great. Our basic capital was only 75 dinars. That was the cost for the paper for the first issue." (Симић 1935h:1) In the previous newspaper issue (number two) on page three is written that "Our brother, J. P., university student, has contributed to our newspaper with 200 dinars. - Thank him." The funding for the newspaper production was not sustainable and came from donations covering the printing costs. Petrović, for instance, might have been the Serb friend who took care of printing the newspaper as narrated by Svetozar Simić himself in his editorial:

One of our great friends, otherwise a Serb and a very popular and respected person in Belgrade, took care of the printing. We survive from issue to issue always in a hope that our work will not be in vain and that finally our brothers will see that one dinar per month is nothing for them, especially when this expenditure is compared to the monthly expenses they make for brandy. (Симић 1935h:1)

It was exactly due to the financial unsustainability and lack of resources for printing that the newspaper had only three issues. There is not much information regarding Romano lil's distribution. The edition advertised yearly subscriptions; however, the bookkeeping documents do not contain exact information on the distribution network or on subscriptions. According to the review in $J G L S$, the copies were given for distribution, but this was a great failure on behalf of the distributor, as cash was received for only 200 copies out of 2000 during the three months of publishing (Jopson 1836:86-87). Dragoljub Acković suggests that the newspaper has been well-known in Yugoslavia as there is a post request which ordered "five copies of the newspaper to be delivered to the bookstore Jaša Dajč from Bačka Palanka, a town located 15o km from Belgrade." (Acković 2009:58) The editorials also point out that the newspaper had several hundred subscribers defined as intellectuals from Yugoslavia, as well as from around the world: 
It seems that the whole world has heard about our newspaper. So far, we have received letters from: Sweden, Norway, Germany, Hungary, and Poland. The English Reuters agency has announced its release to its English reading audience. We do not know to what we owe such great popularity of the first Gypsy newspaper in Yugoslavia. Is it because the whole world considers us so wretched and miserable, so the emergence of such a small newspaper, like ours, is already a sensation for them! If we look at the number of those who are buying our newspaper, we will see that the greatest number of our readers and subscribers are from the ranks of gadže (non-Gypsies), and, furthermore, intellectuals. People of the highest culture are interested in a newspaper of people at a very low cultural level! This is already a success for our first two issues. (Симић 1935h:1)

Apart from enlightening the non-Roma audience of intellectuals, the newspaper has clearly been oriented mainly towards Roma readers, as evidenced by the article narratives and usage of the Romani language throughout all texts. The newspaper itself contains several features, in terms of content, which demonstrate that its targeted audience were Roma. In the first place, there were several advertising publications on the pages of the newspaper pleading for a wider audience and for a specially tailored approach to address the high level of illiteracy. The third issue's last page, for instance, contains the text: "Dear brother, help our newspaper. Read it also to our illiterate brothers, let them also know what our newspaper writes about," while the second page of the first newspaper contained a short advertising announcement on page two saying "Dear readers non-Gypsies and you guglalen pra(h)lalen (sweet brothers) - as many as you are out there, buy and distribute our newspaper!"

At the same time, Simić was well aware of the fact that Roma people had hardly the necessary literacy to access the published materials. While the average illiteracy rate of the Yugoslav population according to the census of 1931 was 51.5 percent (Isić 2001:66), some qualitative studies estimate that it was over 90 percent among the Roma population. Simić came up with a practical suggestion to address the issue, through reading aloud to groups of Roma, which actually had been practiced in Belgrade, as exemplified in an editorial in the third issue:

An interesting attempt was made in that direction by another member of our editorial team, Mr. Milić. He collected in his backyard a group of 15 to 20 men and women of different ages and read to them the newspaper from the beginning to the end. After every article he read, he explained to them in his own words in Romane (in Gypsy language) what he had read to them. Then started the questions that grew up into entire discussions. If we could find more people like Mr. Milić, we could even get a greater interest in our newspaper among our people. (Симић 1935h:1)

In his first editorial it was stated that the newspaper was to both Roma and non-Roma audiences. It positioned itself as a counterpoint to the image of the Gypsy exotic beauties which were published in other mainstream media: 
A newspaper such as ours could be edited in two ways: it could be written about Gypsies and it could be written for Gypsies. If we were to write only about Gypsies, we would have to take into account the various tastes of our gadžo (non-Gypsy) readership. Without a variety of "stars," e.g. black and Gypsy, and their respective pictures, our newspaper would hardly survive. No matter how good-looking, attractive and adorable our black beauties are, we still do not mean to write about them. Our newspaper was launched in order to write about the Gypsies, but of course, for the Gypsies. (Симић 1935а:1)

The newspaper indeed reached the Roma audience. It apparently had a certain level of distribution among the local Roma community as we learn from the address of Marinko Savić, a respected Belgrade Rom, musical band leader and Gypsy kmet (an alderman responsible for communities or administrative territories, in this case on the territory of Belgrade) to the Editorial team published in Romano lil (Савић 1935). Savić expressed his joy to learn of the newspaper. The editor also discussed spreading the word among the Roma in the two Belgrade neighbourhoods where many Roma lived:

Straight after printing the first issue of our newspaper, news has spread among the Gypsies across Jatagan Male and Čubura, that Mr Simić has enormously enriched himself. Whenever he showed up among Gypsies, women and children would say: kava si kaj bićinel novine [that's the one who sells newspapers]. In the simple world of ours, to sell newspapers and to write in the newspaper is the same thing. (Симић 1935h:1)

The four-page newspaper format resembles the format of the Serbian newspapers published by Serbian intellectuals at the end of eighteenth and beginning of the nineteenth century in Vienna: Serbian nеwspaper (Сербскија новини), 1791-1792, and the first daily Serbian newspaper from the imperial city Vienna (Новине сербске изъ царствующега града Віенне), 1813-1822 (Крестић 2003:28-34). These editions were the first ever Serbian language print media, closely interrelated with the ideas of the Serbian national revival and their circulation among the Serbian elite. The first newspaper published in the Principality of Serbia was also named Serbian nеwspaper (Новине србске, 1843) and was published weekly in a four-page format to "disseminate education and culture" (Subotić 1998:75). Thus, naming the Roma newspaper following this pattern (Roma newspaper/ Gypsy newspaper), and publishing it in the same format, was not coincidental. This demonstrated the intention of the Editorial team to implement the same mission - to evoke a raising of Roma community consciousness as a public phenomenon. It followed the model of the national press, developed by the surrounding (Serbian) nation, but was directed towards the Roma community that had to be engaged, united and represented by the newspaper. This conclusion is not only based on the interpretation of Romano lil's name and format, but also on its content, as demonstrated by the words of the editor: "We should not forget that our newspaper has to fulfil a cultural first-order mission." (Симић 1935h:1) 
Although called a newspaper, this print media was published neither daily nor weekly, and was not focused on reporting news. It was a monthly edition, which in terms of content, merged many print media genres: newspaper, journal, brochure. Most of the pieces were written in the so-called opinion article genre, which also evokes comparison with the early stages of every periodical press created as part of the national revival movement (the mentioned above Serbian newspaper from the imperial city Vienna of 1913 or the newspaper Macedonia mentioned in the chapter about the Ottoman Empire of the book), in which the main focus is on polemics related to the cultural and political emancipation of the community and the means for their achievement. These opinion articles reflected their authors' ideas and provided guidelines and programme statements. Even the reportage materials in Romano lil were intertwined with the polemic style of opinion articles. Finally, a large part of the newspaper was devoted to legends, local memory sharing, and presentation of Roma folklore, which is often typical for ethnographic journals or popular magazines. Being the only print media of its time, thus, Romano lil was designed as an all-in-one edition, which combined various styles and genres under the overarching strategic aim to express ideas for Roma emancipation by all possible literary means.

\subsection{Structure, Content and Genres of Romano Lil}

The newspaper's content seemed to be strategically thought out, with all three issues following a similar structure. It always started with an editorial article and ended with a feuilleton, written by Simić. The second page was devoted to narratives of importance of the ethno-cultural life or the collective memory of the Roma community, and the third page contained shorter pieces reflecting on contemporary issues, along with Roma folklore. The articles were mostly written by Simić, with several large pieces by Aleksandar Petrović, and M. Milić, an educated Rom and co-founder of the newspaper (Симић 1935h:1), whose pieces (Милић 1935a, 1935b), judging from their content and rhetoric, were edited and influenced by Simić's own style. There was also one piece by each of the following authors: Jovan-Jovanče Milosavljević (Милосављевић 1935); Dragomir Ilić (Илић 1935) and Marinko Savić (Савић 1935). Although some of the pieces were not signed (editorials for instance, following the usual practice in this genre) they should be attributed to Simić, as the newspaper archive (LADA) contains their versions in a manuscript format, with the handwriting belonging to him.

Below is the content of each issue with the article's/material's title, as well as authors, when available. The table's aim is to provide a comparative perspective for the three issues and to give an idea about the commonalities of the content throughout all editions: 
Table 3.1 Summary of Romano lil's content

\begin{tabular}{|c|c|c|c|c|c|}
\hline No & $\begin{array}{c}\text { Editorial } \\
\text { (first page) }\end{array}$ & $\begin{array}{l}\text { Folklore and } \\
\text { ethno-culture }\end{array}$ & $\begin{array}{c}\text { History and identity } \\
\text { related reports }\end{array}$ & $\begin{array}{l}\text { Opinion article } \\
\text { on contemporary } \\
\text { issue }\end{array}$ & $\begin{array}{l}\text { Feuilleton } \\
\text { (last page) }\end{array}$ \\
\hline $\begin{array}{l}\text { First, } \\
\text { March } \\
1935\end{array}$ & $\begin{array}{l}\text { "Our first } \\
\text { word" }\end{array}$ & $\begin{array}{l}\text { "Our } \\
\text { Antie-Bibija"; } \\
\text { One anecdotic } \\
\text { tale; } \\
\text { One short tale; } \\
\text { One song. }\end{array}$ & $\begin{array}{l}\text { "Our people } \\
\text { mourn their King"; } \\
\text { Request to Roma } \\
\text { readers with } \\
\text { ethnographic } \\
\text { questionnaire. }\end{array}$ & $\begin{array}{l}\text { "To preserve our } \\
\text { and our children's } \\
\text { health" }\end{array}$ & $\begin{array}{l}\text { "Ominous } \\
\text { note" by } \\
\text { Simić }\end{array}$ \\
\hline $\begin{array}{l}\text { Second, } \\
\text { April } \\
1935\end{array}$ & $\begin{array}{l}\text { "To our } \\
\text { readers" }\end{array}$ & $\begin{array}{l}\text { "Djurdjev-dan" } \\
\text { by Petrović }\end{array}$ & $\begin{array}{l}\text { "From the history } \\
\text { of the Belgrade } \\
\text { Gypsies" by } \\
\text { Milosavljević; "Our } \\
\text { hospitality" by } \\
\text { M. Milić }\end{array}$ & $\begin{array}{l}\text { "For our children" } \\
\text { by Petrović }\end{array}$ & $\begin{array}{l}\text { "You would } \\
\text { have married } \\
\text { twice, if you } \\
\text { were born } \\
\text { before" by } \\
\text { Simić }\end{array}$ \\
\hline $\begin{array}{l}\text { Third, } \\
\text { May } \\
1935\end{array}$ & $\begin{array}{l}\text { "Romano } \\
\text { lil" by } \\
\text { Simić }\end{array}$ & $\begin{array}{l}\text { "Landlord's } \\
\text { wedding at } \\
\text { Čubura"; } \\
\text { One tale; } \\
\text { One song. }\end{array}$ & $\begin{array}{l}\text { "Our uncle Marko" } \\
\text { by Simić }\end{array}$ & $\begin{array}{l}\text { "Our intelligentsia } \\
\text { and aristocracy" } \\
\text { by M. Milić; } \\
\text { "We and our } \\
\text { children" by } \\
\text { D. Ilić; } \\
\text { "About begging"; } \\
\text { "To our brothers" } \\
\text { by M. Savić. }\end{array}$ & $\begin{array}{l}\text { "Lira" by } \\
\text { Simić }\end{array}$ \\
\hline
\end{tabular}

Because of the cohesion and correspondence between the texts, the analysis focuses on the written corpus on the pages of Romano lil as a whole, grouping the pieces from the three issues, depending upon the type of genre and subject covered. The overview below summarises the content and main topics discussed. Selected narratives' analysis follows in the next subchapter.

The editorials are constructed in the classical form for this publicistic genre and can be viewed as programmes, not only for the publishing activity of the editorial team, but for the Roma community in general. They appeared at the beginning of each Romano lil issue and, following the editorial genre style, express opinions, argue different viewpoints, analyse facts and events, and manifest the newspaper's aims. The opening editorial of the first issue, "Our first word" (Симић 1935a:1), addresses two big matters related to different strata of the Roma community. The first one is related to the poverty of the Roma. The author's explanation is that "our brothers" are poor because they are not 
educated, although they have some practical skills in many crafts. Efforts, thus, need to be made among the community to improve the educational level.

The second matter is related to the fact that many educated and well-off Roma are in fact distancing themselves from the community because of the mainstream misconceptions about Gypsies as thieves and criminals, deeply grounded in the public discourse and maintained by the media. Finally, the editorial addresses the issue of perceiving begging as a Roma characteristic and practice. The editorial ends by presenting the goals of the newspaper, to address these issues existing in both the Roma community and the society:

That's why we have launched our newspaper. With it we want to open our brothers' eyes and show them that it is our first and foremost task to send our children to school, in order to become literate, and to let them learn some craft or skill right after graduation. [...]

Our newspaper will do all in order to give our brother a helping hand in his culture, and this means, a mental and material improvement. - On the one hand, we will give readymade knowledge and statements, and on the other hand, we will show the paths that lead to them. (Симић 1935a:1)

"To our readers" is the second issue's very short editorial. It provides a self-reflection on practical problems of pricing, distribution and reaching out. It ends with an appeal and question to the newspaper's readers: "Do all our brothers read our newspaper, if they have read the first issue did they understand it well, and what did they not like about it. We would be glad to hear the opinion about the newspaper of every single reader of ours." ([Симић] 1935:1)

The third and final issue's editorial, "Romano lil", reflects on the successes and challenges that the newspaper has faced during its short existence. It informs the reader about the newspaper's international recognition: "English Reuters agency announced publication of the paper to its English reading audience." (Симић 1935h:1) English media published brief information about the Belgrade Gypsy newspaper and its Roma editor, for example the article "The First Gypsy Newspaper. Printed in 2 Languages" in The Telegraph of May 18, 1936. In the text of the Romano lil's editorial, the international success is contrasted to the community reception and some unintended effects, like perceiving the editor as someone who made a fortune. The text further appeals to those who are more educated, to disseminate the newspaper and its contents, and finally asks for more engagement from all community members, especially those who are literate and can influence the public opinion or assist in distributing the contents of the edition.

A substantial part of the newspaper's materials was devoted to Roma ethno-culture and folklore. There were two types of articles. The first text discussed customs and celebrations related to important identity markers of the community, and the second text included records of Roma folklore in the form of songs, short tales or anecdotes in Romani language, followed by Serbian translation. This is not coincidental and is related to the wish of the publisher to provoke identification with "certain poems and stories 
printed in a language spoken by them, our people are turning to more serious things, to our life in general." (Симић 1935 h:1) Language has been one of the most important markers of identity in CSEEE context and language policies have been closely interrelated with the nationalism movements (Kamusella 2018). These materials were thus carefully picked to reflect the Roma community identity. Probably the two most important celebrations for the Roma community in Central Serbia, that function as markers of Roma identity (for both Roma and non-Roma) to the present, are the belief in and celebration of Bibija and the celebration of Djurdjevdan, that is the Day of St George on May 6. There are even disputes among the Roma themselves concerning which of the celebrations is 'more' Roma (Acković 2013). It is thus not surprising that publications related to these important markers of Roma identity, occupy a central place in Romano lil.

In the very first issue of the newspaper, a one-page article, "Our auntie Bibija," was published ([Симић] 1935b). Among Roma in Belgrade and in Central Serbia Bibija is celebrated as an uncanonised 'Gypsy' Saint that protects Roma children from dreadful diseases and secures health for them and their families. An oral folklore narrative, in various versions, explains how Bibija cured and helped Roma children during a plague epidemic. The name Tetkica Bibija is included in both the Serbian (Tetkica, in diminutive) and Romani language (Bibija), a term for the word Auntie, a substitute name for the Plague. In the folklore and calendar customs of many communities in South Eastern Europe, the Day of the Aunt (or the Day of the Plague) is celebrated with different components and prohibitions that have to secure protection from diseases, especially for the children (Попов 1996). It has developed and been perceived as a specific Roma custom, the Aunt thus presented as a black Gypsy woman in narratives and in iconography (Acković 2004, 2010; Petrović 1937). Romano lil provided accounts of the legend about the saint and the reason why Gypsies celebrated her. The article describes her with words in Romani language. In the following excerpt from the article the Romani words and phrases are left in the original language to communicate the effect that the author wanted to achieve, while the Serbian text will be translated in English:

She was from our kind. Black as every Gypsy woman, Bari, (high), cući, lean, kokaluni, (scrawny), lungoni ando muj, (long-faced); kale jak(h)a sar angara, (black eyes like coal), that look towards the sky, baro nak, (big nose), baro muj, xurde danda thaj cikne vuš, (big mouth, small teeth and thin lips). ([Симић] 1935b:2)

As seen in the media reports on the Bibija celebration in Belgrade (Политика 1926), as well as in the fact that a civil Roma organisation was named after her, worship celebrations were intertwined with civil activities and commemorating practices of importance for both the ethnic (Roma) and national (Serbian, Yugoslavian) identity of the Roma citizens. It was important to publish this narrative, not because the legend is unknown to the community, but because of its representational purposes: it reaffirms the importance of the custom and celebration of the identity of the community and their differentiation from the Serb community. 
In the second issue of Romano lil, an article is published by Dr. A. Petrović about Djurdjevdan (Петровић 1935c), the other celebration considered a Roma marker of identity by both the Roma and the non-Roma. The article is a reflection rather than an exact description, since all readers are acquainted with the celebration, but it refers to important elements of it: like going early in the morning to the river, wearing their best and newest clothes, and attending big community gatherings and meetings. The celebration unites all Gypsies, regardless of their way of life and religion, according to the narrative. Thus, nomadic Gypsies would come together in a certain place, being glad that the roaming season starts, while the settled would also be happy because the warm weather brings changes. Similar to the publication about Bibija, the material reaffirms Djurdjevdan's importance for the Roma, as a common and special custom that unites them as one people.

Wedding customs, along with other customs from the life cycle, such as those related to birth and death, play an important part of the community ethno-culture. An article by Simić, in the third issue of Romano lil, "Landlord's wedding at Čubura," describes a wedding from the famous Belgrade neighbourhood (Симић 1935j). It is written as a reportage, in an impressionistic style typical of the journalistic discourse of Yugoslavia of that time but contains descriptions and phrases in the Romani language. It portrays a rich wedding in which the whole Belgrade Roma community was gathered:

Along the neighbourhood yard are put ten tables. Perdi sinija ali jak [in Romani language]All tables as full as an eye. On every table there is baked bread. Pećipe: bakrano, buzikano, ćuranosko, bašnesko t(h)aj sosko kod kames - Roasted meat: lamp, goat, turkey, chicken, rooster and whatever you want. Samo čirikljako tud kaj nas - Only chicken's milk was missing.

The bottles were arranged one next to the other as in a bar. Lazy toasts from all around with bottles. Songs, music and joy. There are violins, there is an accordion, bas, tambourine and brace and whatever you want. All kinds of musical instruments. While the elders were sitting, singing and drinking, the youngsters dance in a kolo. (Симић 1935j:2)

The legends, short stories, songs and oral history materials published in the newspaper, should be interpreted in the Volk-spirit discourse - they (re)present Roma folklore as part of the Roma people's culture. The non-Roma audience should get acquainted with the rich Roma folklore, while Roma people should identify with it. The materials selected are short, often of a humorous nature. The rubrics had Romani language names, "Amare gilja" (Our songs) and "Amare paramiča" (Our tales/stories), thus reinforcing a common identity. The first issue contained the following tale:

There was a Rom in a village. He works at one gadžo. One day, at the field, the gadžo brings food for a meal. Then everyone gathers to eat. The gadžo asks: "who is going to take this big slice of bread?"

The Rom would say: "I'm going to take it?"

Then [the gadžo] asks: "Who is going to take this bacon?"

The Rom would say: "I'm going to take it?" 
At the end the gadžo asks: "Who is going to take this big hoe?"

The Rom would say to this [question]:

Brothers, I talked too much, now you speak too. (Romano lil 1935a:3-4)

In the Romano lil's third issue there is a story published by Simić, created in the form of a folk tale narrative, and named "When the Serb was afraid":

A Rom came into at a Serbian man's shop, had a look at all items, and said:

How much is this halter, boss?

- It's three groats for you, Roma man, for the others it's four.

- Common, bro, give to me for two.

- I would not sell it for less at all.

- Give it to me for two otherwise I'll do what I have in mind!

The Owner got scared, took down the halter and sold it to him for two groats, and when he got the money, the seller asked him [the Roma]: Would be good to tell me, what did you have in mind to do to me, Rom, had I not given it to you for two groats?

- Let God kill me, if I had not thought to give you three [groats]!

Said the Rom and went away happy. (Симић 1935k:3)

The texts of the popular songs, "Who is the one that is coming" and "Stand up, Rom, do some work," appeared in "Our songs" section in the first issue and the last issue of Romano lil (1935b). All folklore materials were published bilingually: in their Romani language with parallel translations by Simić in the Serbian language (the English translations above are done by me, following the Romani language originals as published in the newspaper). The main reason for having exactly these materials published was not strictly speaking because of their content, but the fact that they were considered representative as folklore, due to their popularity among the Belgrade Roma community. Additionally, the Romani language has always been also a symbol of Roma identity, for both Roma and non-Roma readers.

The publicistic texts related to records of narratives about community life discuss the history and identity of the Roma as an inseparable part of the larger Serbian and Yugoslav society. The very first issue included an article entitled, "Our people mourn their King" ([Симић] 1935c) about the assassination of King Alexander First, the Unifier in 1934. It describes the reaction of the Roma people to the news, varying from questioning its truth, to rage and anger against the assassin, and deep sorrow at the end:

When newspapers [reporting the assassination] were published, one person would read while the rest of the people would gather in big groups around him, intently listening to him read the article. A drizzle would start raining, but we, instead of going home, have taken off our hats, talking: "I o Del rovel, i Vov (h)aćarel o dji" (And the God cries, He feels compassionate as well). ([Симић] 1935c:3). 
The other articles are connected with records of the historical events as narrated by the Belgrade Roma community. The material, "From the history of the Belgrade Gypsies," had probably been narrated to Simić as an oral history, later recorded, published and signed by the narrator, Jovan-Jovanće Milosavljević (Милосављевић 1935:2-3). It contains a vivid and informative account of the dynamic community development - including numbers of families, groups, settlements and leaders - from the Serbian principality under Prince Mihailo Obrenović (1839) until the First Balkan War (1912). While the article focuses on the development of the community against the background of the overall historical periods in Serbian history, the article "Our uncle Marko" by Svetozar Simić in the third issue elaborates on the contribution and the role of Roma individuals, as part of the Serbian army during the First World War (Симић 1935i:2). Marko Vasiljević was a respected Rom from the neighbourhood of Čubura who had proven himself as a great and heroic soldier when serving in the army, for which he was awarded the highest decoration of the time, the Order of Karadjordje Star. The narrative of Vasiljević, recorded and printed in the newspaper starts with:

- Ala mudardem len, ali džuklen. - But I have, brother, killed them as dogs. I have fought at: Ada Ciganlija, Banovo Brdo, Čurkarica, Zaklopača, Varonice where I have been awarded with the "Karadjorjde star." (Симић 1935i:2)

The articles about the grand national narratives are complemented by minor stories about the community's everyday life as “Our hospitality" by M. Milić (Милић 1935a:3-4), in which the message is communicated that hospitality is one of the main characteristics of the Roma people which distinguishes them from the others, the Serb, i.e. functions as a marker of identity, and is maintained unconditionally regardless of the material situation:

Even though we are poor, and often do not have a decent bed in the room, we are always ready to give the best place to our guest, even if this means that we will sleep with our small children on the bare ground ... The guest will get the best piece of the meal. Nothing should happen to the guest as his security is guaranteed by the host ... Are our youth going to save this old custom? De Devla! (Let it be God!) (Милић 1935а:3-4)

Although the newspaper does not pay attention to daily news reporting, its opinion pieces cover current issues of significance for the Roma. Similar to the first editorial, awareness is raised among Roma adults regarding Roma children, their wellbeing and education. The article "To preserve ours and our children's health" ([Петровић] 1935a:1935) informs the readers that they have to take care of their health. It also provides practical information, such as that the state has opened, free of charge, health centres for servicing those who are not able to pay. "To our Children" is the central article of the second Romano 
lil issue (Петровић 1935b:1-2) and is written by Petrović. The main point of the article is that the best way to preserve children's health is by not getting sick yourself and not transmitting diseases to your children. According to the piece, the most dangerous diseases are those that come "from sin" and are transmitted by blood, concluding that: "The question of health and advancement of our children is a question of the fidelity of our men to their wives and the fidelity of our wives to their husbands." (Петровић 1935b:2) Another aspect of parental responsibilities is discussed in the piece by Dragomir Ilić, "We and our children" (Илић 1935:3), namely the effect of exposing children to the environment of kafana (tavern in which people gather to socialise, drink and discuss all kinds of issues from local gossip to international news). According to the author, drinking habits, indecent speaking and gambling models would be observed uncritically by children if they are brought to kafanas by parents, concluding: "Brother, have you ever asked yourself: what do you do with your children when bringing them to the kafana? Strike the iron while hot, train children in good habits while small." (Илић 1935:3) Finally, in "Our intelligentsia and aristocracy" another reflection on the contemporary situation among the community is discussed. In the piece, M. Milić criticises the successful strata among the Roma that do not support the community (Милић 1935b:2).

The original fiction literature on the pages of Romano lil newspaper comprised three feuilletons authored by Simić: "Ominous note" (Симић 1935e), "You would have married twice, if you were born before" (Симић 1935g), "Zira” (Симић 1935l). They are characterised by satirical style, documenting and elaborating on stories heard, witnessed or experienced by the author himself. "You would have married twice, if you were born before" resembles a short story with descriptions of the poor life of Roma living in tents, who agree on marrying their young daughter to an older Rom who had already been married. "Ominous note" and "Zira" are written as humorous narratives about urban youth. In "Ominous note", the main hero, the young Gypsy Djokica, tries to arrange a date with the beautiful Rada by sending written notes to her, which infuriate her father. The final surprise comes when Djokica finds out that Rada had already been engaged to be married to another man.

"Zira" tells the story of Simić himself, who was pushed into an engagement against his will. Zira is a Roma woman who divorced after a short marriage. Her father brings the journalist home, introduces him as a world-known star and tries to talk him into marrying the woman. The main hero and victim of this arrangement makes an effort to argue against this, and finally runs away, on the pretext of having writing obligations:

- Zira, Zira, my daughter, my child, my kid, I brought you a groom, a journalist, a guy as a shaker, his hands are gold, making money on all sides. His guests are journalists, judges and the high ranking directors and officers from all over Europe. They are from Pešta, Paris, Berlin and [from many places that] I cannot name. And you, my child, have a lot, so good for you and for him, and also for me by your side. Hopefully you will not forget me.

- He wouldn't take me, I'm a stupid one! Otherwise I'm ready with my soul and body, as the Gypsies from Leskovac say. 
And I told her then, Zira, Zira, don't run away from your happiness, but wait for the priest to add some more years to my age. I don't want to be married around the willow [e.g. to not be married in a church because of being underage]. That's why you have to wait. Then I storm out saying: good buy, good buy! I apologise, but I don't have time right now, I'm writing an article for "Romano lil." Svetozar Simić (Симић 1935l:4)

The motif about a successful Roma man being an object of engagement against his will reoccurs in several of Simić's texts. For instance, the editorial in the third Romano lil issue (Симић 1935h), and the unpublished novel, which remains only partially preserved. This motif has probably been related to the autobiographical experience of Simić himself, as well as with observations among his peers. In the original Romani literature pieces, published in the newspaper, the heroes are Roma characters in Roma community surroundings. Although the stories are very short, and there are no generalisations suggesting a collective representation, the plots can be considered typical and illustrative of the interpersonal and intergenerational relations within the Roma community.

\subsection{Narratives of Self-representation}

Despite the short four-page format, the newspaper's content comprised a variety of journalistic genres and styles: from the opinion pieces, through identity representation by folklore and history publications, to original literature writings. There is a coherency, not only in terms of genres and topics covered, but also in terms of narratives communicating common messages to the audience of Romano lil.

Being a Roma newspaper, the overall narrative of the edition suggests a (re)presentation of a Roma collective. Speaking about Roma/Gypsies, the newspaper's authors used the pronouns of first-person plural, e.g. "we," "the Gypsies," "our people," "our brothers," "our children," "our friends," in all newspaper texts. This way of writing suggests an 'imagined' Roma community (in the sense of Benedict Anderson 20o6), a collective comprised of all who are Roma/Gypsies. "Naš narod" (our people) is also a common phrase signifying a distinct community, different from the other people, along with "our brother(s)" and "our brothers and sisters" (Симић 1935b, 1935c, 1935h). This, on the one hand, is a rhetorical construct among the Roma when addressing other Roma; 'brother' and 'sister' are terms used between Roma in general, not only in family relations (this practice is used, following the same pattern, among the surrounding population as well). On the other hand, it also presents the idea about the unity of the Gypsies, who are part of the same family or kin. This narrative is a clear example of a birth of a primordial concept for an ethno-national community united by common origin and belonging.

Simić talks on behalf of Gypsies (speaking of "our people", "we the Gypsies", using verbs forms in first person plural), while at the same time addressing the Gypsies. The most common way of addressing the Roma audience is "our brothers," and the Romani 
language phrase гуглален пра(х)лален (sweet brothers) followed by its Serbian translation (Симић 1935a, 1935h). The use of this Romani language address for daily communication suggests intimacy and warm feelings, which should also stimulate a Roma audience identifying with the author of the text. It also legitimises Romani language salutations in print as well as public communication, thus strengthening the self-esteem of the Roma readers.

Another interesting feature of addressing the Roma is the special emphasis on both genders - Simić often writes "our brothers and sisters". This points to the equality of female and male personalities in the Roma collective. The texts even talk about the specific problems of "our sisters," meaning Roma women, when discussing the lack of literacy (Симић 1935h:1). Thus, Roma women were viewed as equal to men and not as subordinated or right-less individuals. At this point we can include another example from the history of Roma activism in Yugoslavia supporting this statement: According to article 11 of the Statute of the Association of Belgrade Gypsies, worshippers of Auntie Bibija that was contemporary to the newspaper (established in 1935) "Any person (of both sexes) who lives in Belgrade can be a regular member of the Association, assisting members, founding members and benefactors of the Association can be any person." (Marushiakova and Popov 2021a:199-200)

The content of the narratives themselves also communicate ideas about the collective that is different from the others by specific markers of identity. Such a marker is the already mentioned Djurdjevdan celebration, and the article about it contains very important statements for its collective representation of Gypsy people as one people united by a common culture and history:

All the people have their own celebrations. These are days related to memory about some event from the life of this people or days of birth or death of people who served to this people. And we the Gypsies also have our great people's celebration. We do not know if this celebration is related to an event from our history as we do not have a written history. Even our legends about it do not say anything about that. But still the celebration of Djurdjevdan is closely related to our people's life. The rest of the Christians also celebrate Djurdjevdan. It is honoured by the Muhamedans as well. But no one expects it with the same joy and merriment as we the Gypsies. (Петровић 1935c:3)

The unity and identity of the community is communicated also through its differentiation from the others. The claim for differentiation is that, unlike Roma, the rest of the communities do not celebrate Djurdjevdan in the same manner.

Although the newspaper articles are based on information about the culture, history and memory of the Roma community in Belgrade or Central Serbia, the narrative refers to a general collective, presenting Roma/Gypsies as one people and thus suggesting a common sense of belonging. The editor is, of course, well aware of the non-homogeneous, still common, nature of the Gypsy community. Romano lil's authors demonstrate awareness about the different Gypsy/Roma groups. In the first issue a material was published 
entitled, "Where do we live and how many of us are" appealing to "every brother of ours to the hands of whom comes our newspaper to send information and data about their place of living, Gypsies who live in the place, occupation, time of settlement, languages spoken and religion." ([Симић] 1935d:3) Through the wish to collect information about the internal diversity among the Gypsy/Roma, the newspaper narratives reinforce the sense of unity and create the impression that all Roma should go in one path and belong to a whole.

Along with the idea of Roma as a collective, the Roma belonging to the macro-society / nation state (e.g. Serbian, Kingdom of Yugoslavia) is expressed. As Marushiakova and Popov (2016a: 15) have pointed out, Roma have not only a sense of belonging to the Roma community (at the level of their own Roma groups, subgroup or meta-group), but also to the macro-society with which they constantly interact and are part of. Roma do participate in the social system, public and institutional life of their respective nation state, identifying with the symbols, national figures and events that symbolise the unity of the nation. The sense of belonging to the national community (e.g. the Kingdom of Yugoslavia) is clearly expressed in the already mentioned "Our people mourn their King" that discussed how the news about the assassination and death of Alexander I (December 16, 1888 - October 9, 1934) was perceived by Roma. The assassination took place almost half a year before the publication of the issue, but it seems that the event was of such significance for the Belgrade Roma community, so it was important for the editor to express the belonging to this community to the people of the Kingdom, e.g. the body of the nation. The article reports that "All of us were full of deep grief: everyone felt that he has lost his Protector, his Father ..." ([Симић] 1935c:3)

Interestingly enough, this is the Serbian language text published in Romano lil with the largest usage of Romani. The editor reports the reaction of the Roma in Romani language with phrases and gestures that are common and characteristic for the community on occasions of deep grief and emotional state, thus providing authenticity of the narrative, followed by Serbian translations:

Ah, phabilam, bi baxt bari - Ah, we are lost - we are burned, a big infortune! Along with this, our women were pulling their hair and cursing the children of the one who did it. They were cursing also the dead assassinator, saying: Dear God, Dear God, with what kind of heart could he do it? Sar savo soro sasle? (How could he dare do it). Our people were beating their breasts with fists. If the children, excited by the behaviour of the adults, started making problems, they were cursed: 'Majlac(h)e baksuzona te mylana tu, (haj) te kava na ashunav' (You'd better be dead, Jonah, rather than the news I have heard). Some were talking: 'We have lost a Lord, who was the dearest to us after God and the Sun'. Others would swear: "Let God kill me, if it was not better for me to have all my children killed and my house burned down." ([Симић] 1935с:3)

The Romani phrases characteristic of mourning portray the Roma as an integral part in the Kingdom. The narrative suggests equality among the Gypsies and the other 
communities constituting the Kingdom, but expresses grief from their own community stance:

If some of us had a dinar, he would with this very last money buy rakija, spread on the ground the first drops [done for the soul of the diseased according to the custom] saying: Let him rest in peace and be glorified, brothers! He loved us and took care of us as his own children. And he did not make any difference between Gypsies and Serbs, Croats and Slovenes. He protected all of us equally. For every Easter and Christmas he gave us support from his own salary. ([Симић] 1935c:3)

"Our Uncle Marko" also contains a narrative that should be interpreted as an expression of Roma belonging to the nation state. Many Roma took part in every war that the Serbian army undertook ever since the nineteenth century. After the First World War there were many war veterans and also many Roma who lost their lives in the wars in which Serbian citizens were involved (the Balkan Wars and the Second Word War). After the wars, Belgrade Roma, from the charity Club of Belgrade Gypsies (probably an informal organisation at that time), organised themselves and built a monument devoted to 54 named Gypsies who died during the Balkan Wars and The First World War, as reported in Serbian media in the 1920s (Acković 2017a; Политика 1926). Along with Marko Vasiljević, such heroes included, Amed Ametović, a.k.a. Ahmed Ademović, trumpeter of the First Serbian Army, who played a key role in the Battle of Kumanovo on 24 October 1912, and later took part in the Second Balkan War and in the First World War; as well as the First World War participant Rustem Sejdić (Симић 1935i:2; P. L. 2018). All were awarded with the highest commendations for their heroic participation (Order of Karadjordje). These Serbian Roma war heroes became a source of pride in the respective Roma communities and among Roma activists who were seeking recognition of the Gypsy citizens' participation for realisation of Serbia's national ideas (Acković $2017 \mathrm{~b}$ ). This was in unison with the state post-war identity and memory politics: the war veterans and invalids of the Balkan Wars and the First World War had a very respected position and were considered heroes in the public discourse of the Serbian society in the 1920s (Šarenac 202O).

The most strategic pieces in the newspaper are the editorial articles devoted to visions about what Roma should do for a better future. In them Svetozar Simić shared his statements that outline an agenda for his own community's development. In his first editorial we read:

Nowadays, in order for a person to be able to earn a slice of bread for himself and his children, he has to fulfil at least two conditions: to be literate and to have in his hand a permanent occupation ...

And we think that the only remedy for this evil and embarrassment is that every one of our children attends a school, and after the end of the school is immediately sent into some craft or some skill. A man who starts to work from childhood, gets used to it, and can never be without work ... (Симић 1935a:1) 
The last issue of the newspaper also contains an article relating to the visions about the Roma community development and the need to improve the way of life of the Roma. The means for this are:

We should not forget that our newspaper has to fulfil a cultural first-order mission. From the interest in certain poems and stories printed on a language spoken by them, our people are turning to more serious things, turning to our life in general. The question of improving our way of life is largely in our own hands ... The future will show, if we would be able to convince our brothers and sisters how important it is for each of our children to complete elementary school and learn some crafts. ([Симић] 1935h:1)

Reading these pieces as programmes which shed light on both problems and their solutions for a desirable future of the Roma, we can see essentially three main points, or priority areas, in which Roma have to concentrate. They are all related to the Roma children or the future generations among the Roma community. They are interconnected: In the first place, Roma have to take care of schooling their children ("first and foremost task to send our children to school, in order to become literate"), secondly, this has to be followed by professional training securing an occupation and regular work ("and to let them learn some craft or skill right after graduation"). In addition to this, Roma have to elevate culturally by gaining experience and knowledge about the world and the people and this is to be achieved by the engagement of the experienced, educated and active Roma from the older generations. What is interesting to point out is the fact that these visions, for the desired development of the Roma community, are not related to demands from the state, political or government measures, but to demands from the Roma themselves ("The question of improving our way of life is largely in our own hands"). The author's aim was to emphasise on and raise the issue of Roma's own agency, initiative and selforganisation to achieve a better future through using the already existing mechanism in their environment.

In relation to the need for a Roma agency in achieving a better life for the Roma as a collective, some parts of Simićs articles also engage in a critique from within the community and disapproving actions, views and habits among the Roma that prevent them from reaching prosperity and, in the words of the newspaper, "elevate to another cultural level" (Симић 1935h:1). There are two common themes in this respect that appear in more than one issue of the newspaper. The main critique, observed in the editorial articles by Simić, is to the Roma community itself for not paying enough attention to the schooling and professional skills of their children, as well as for the lack of interest to Roma civic activism. The second critique, expressed in articles by Petrović, is the negligence of the importance of health issues, especially children's health ([Петровић] 1935a; Петровић $1935 \mathrm{~b}$ ). The third editorial criticises Roma for neglecting their own and their children's opportunities for success: 
A little more economy in the house, higher order and cleanliness: a little less visit to the tavern, less card-playing, less drunkenness; and most of all, more literacy, paying more attention to our children and their preparation for the future life, we will live much and much better. (Симић 1935h:1)

But his main critique is directed toward the educated and successful Roma, who, according to the newspaper narratives, are to be blamed for not improving the situation in the whole community. In his first programme article Simić criticised the educated auditory, those who have succeeded in society and enriched themselves with their professions and status, asking rhetorically: "And then why, sweet brothers, our richer brothers are ashamed of their own brothers, their name, their blood?" (Симић 1935a:1) In "Our intelligentsia and aristocracy" signed by Milić, but clearly influenced by Simić's style, we read:

Among us however, they are lords. But the only problem is that they are ashamed, even though they were also born by a Gypsy woman and breastfed with her milk. But they can do a lot for us. Can't they be more engaged with this, until literacy spreads among our people? Can't they create one association that would assist us in a case of sickness and death. They can help us create reading rooms and courses for our illiterate adults. They could help us a lot so that every child of ours learns a craft and profession and honestly earns his bread.

Unfortunately, they do not do anything of this. Just the opposite, those who call themselves 'Gypsy intelligentsia' and 'Gypsy aristocracy,' doctors and other state servants are openly against our newspaper. They spread the word among our illiterate brothers, especially among women, that our newspaper only disgraces the Gypsies, that the owner of our newspaper is against Gypsies, and that no Gypsy should read and support the newspaper. (Милић 1935b:2)

A similar critical message is conveyed by Simić when reflecting on the effect of the newspaper publishing among Roma in contrast to gadže, or the non-Roma:

And now let's see what success has our newspaper achieved among our Gypsy brothers ... The vast majority of our brothers, and not to mention women, our sisters, - are illiterate. Understandably, our newspaper cannot count on their support. The other, literate minority, with little exception, does not read anything at all. And when reading, they are interested in various sensations, such as murder, theft, quarrels, trials, etc. ... Many do not even want to have writings about the Gypsies. They say: "That Gypsy newspaper is just disgracing us." (Симић 1935i:2)

This is a criticism of Roma's lack of civic engagement and a lack of commitment to activities that benefit the Roma community focusing on its prosperity. The main critique addresses those who are literate and educated, as they are the ones who are supposed to have an active role to lead their own community. The texts portray them, however, as either passive and uninterested towards topics discussed in Romano lil, or as people with a negative opinion towards the Gypsy newspaper because it engages with problems existing among Roma. 
In the interwar period, across many countries, the issue of public health was raised and this often went hand-in-hand with eugenic policies (Tanner 2012). In the spirit of the time, Romano lil published two pieces devoted to children's health and promoted free public health services, offered by the state. These texts insist that Roma are negligent towards their health despite the fact that health is one of the most important values for the Roma:

Sastipe si majbari bax, health is the biggest happiness, says our people's wisdom ... health is, dear brothers our biggest happiness, why does not each of us take care about it? ... Well, but many of our brothers who say: I buy bread because I have to, but I do not go to the doctor's as I can bear with my illness a bit. (Петровић 1935 b)

What is interesting to note is that the texts are clearly directed towards a Roma audience, since the authors use arguments with examples from Roma cultural practices and concepts. The Romani language phrases would apparently appeal to them and convince them of the relevance of the issues discussed. What comes to mind when reading this critique, are the similarities with the writings of activists in other countries (Romania, Finland, USSR), discussed in the chapters of this volume, as well as with the present situation and writings or statements by some activists from Eastern Europe, directed to a Roma audience; critiques focused on the issue of successful Roma concealing their Roma origin because of the negative public opinion towards the Gypsies.

The fact that the main issues discussed by the newspaper articles are related to a critique towards their own community, does not mean that the image of the non-Roma is completely absent or that critique towards the majority community is not present. The most frequently used term, the non-Roma word in the Serbian language articles of Romano lil, is the Romani word proper, namely zaђe, provided in its Romani language original, followed by a Serbian translation (нецигани). In this way the edition positions itself as a Roma/Gypsy newspaper that represents the Roma point of view. It also introduces the Roma concept to the non-Roma audiences. The Serbs, being the non-Roma population with whom the Roma from Belgrade are in contact, are also present as a term for the non-Roma, in tales and oral folklore narratives, published in the newspaper, but also when referring to the non-Roma audience in general: "From our brothers, Gypsies, as well as from their friends, the Serbs, depends the further destiny of our newspaper as well as whether its volume will increase or not." ([Симић] 1935h:1) On the one hand, the Serbian community is the "Other," from which Roma differentiate. The differentiation is expressed not only in naming, but through anecdotal narratives, in which Roma protagonists ridicule, in a thoughtful and clever way, a zajo. On the other hand, they are also the most closed ones and allies of the Roma, called friends, who form the Romano lil readership and are addressed by the newspaper writings.

The newspaper editorials ([Симић] 1935a, 1935h) engage in a critique of the macrosociety and primarily its misconceptions about the Roma existing in public discourse. 
Simić addresses two of the most common and widespread misconceptions throughout all historical periods and geographical areas which concern the Gypsies: 'Gypsy criminality' and 'Gypsy begging.' From the position of a Roma run newspaper addressing a wide reading audience, the Romano lil's editor discusses and challenges narratives that were characteristic of the mainstream media. Among these were reporting criminals and criminal activities, not by naming the perpetrator, but by pointing out, in the first place, the fact that the perpetrator was a Gypsy, suggesting equating criminality with being a Gypsy in general. Indeed, even a superficial look into the media of the time, shows that most of the materials are related to reporting illegal and criminal activities by Gypsies. Simić, a law student at Belgrade University at that time, also disputes the legal absurdity of attributing collective guilt to individual criminal acts:

All Gypsies are not and cannot be guilty if one of them breaks the law, and the newspaper instead of saying: this and that, by name and surname, did this and that, they report in large bulky letters: Gypsies have stolen ... Gypsies have cheated ... Gypsies have killed ... Gypsies have been mutilated ... have blinded ... Gypsies ... Gypsies ... Gypsies[.] As if there is not a single criminal act in the world in which a Gypsy guy has not been involved. In human history, there has not yet been such a case in which what an individual, belonging to given people, may have done, is attributed to all the people. And all Gypsies could never answer for the deeds and idleness of individual Gypsies. ([Симић] 1935a)

Another misconception of $\operatorname{gad} \check{z}$, that is discussed and deconstructed, is the equalisation of Gypsies with begging practices.

Many gadže (non-Gypsy) think that a Gypsy and a beggar are the same thing. However, this is not the case.

There are two types of begging. The first is: when a man loses his job, he is hungry, his children are hungry. If the state or the municipality does not help him as a citizen of this country, then only two exits are left to such a man if he does not want to die of starvation: either ask for a piece of bread or steal it. Asking for a piece of bread is forbidden neither by religion, nor by law. Only the one who steals is punished. The second one is the kind of begging, when a person, instead of working, goes around and in various ways, lures money from honest and pious people for bread. We, all the Gypsies, whatever number we are, are against such kind of begging. We fight and will fight against it. ([Симић] 1935a)

Simić challenges the wrong notion of begging as a Gypsy cultural practice, by providing an explanation related to the social circumstances in which every person can find himself. Indirectly, he hints to the fact that if the social infrastructure of a state cannot provide for its citizens in a difficult situation, then begging is just a survival strategy. Furthermore, Simić criticises begging as a practice misused as an occupation replacing proper work. He ends up with a clear message that begging as an occupation is unacceptable for 'all Gypsies' who are against it and who will fight it. The topic reoccurred in the third issue of the journal where an unsigned piece criticising begging practices was published (Romano lil 1935c:3). As a matter of fact, both non-Roma narratives (about 
equating Gypsy with criminal and with beggar) challenged by Simić are still present in the public discourse and continue to be addressed by Roma activists in Serbia and across Europe (Zahova 2020b:294-295).

\subsection{The Fiction Works of Simić: Beginning of Prose Writing}

The Roma publications in interwar Yugoslavia represent a typical example of the early stage of the development for any national literature. In the absence of a state and/or in the process of national revival, led by an educated elite, the first literature works are those that appear in print media periodicals. Similar to all periodicals that provided platforms for these processes, Romano lil also contained short pieces covering all journalistic genres, folklore, as well as literature pieces in shorter form, i.e. short stories, feuilletons, and poetry. It should be noted that while the published pieces were mainly polemic writing, there were also other literature forms produced that have not been published until today.

Svetozar Simic is the author of at least two novels in manuscript form, which makes him one of the first Roma novelists not only in Yugoslavia, but also globally. His first novel, Gypsy (Циганин in the Serbian original), was autobiographical and written in the early 1930s. The manuscript was sent to the mainstream Belgrade publishing house Privreda. Simic got the manuscript back with a standard rejection letter from the publisher dated February 5, 1935. Only the cover of the manuscript has remained of this unpublished novel and is preserved in the Personal Archive of Dragoljub Acković, along with the rejection letter (LADA, f. Svetozar Simić; Acković 202O). The rejection should neither be interpreted as a prejudice towards the author, nor as indicator of the novel's qualities. Publishing a novel requires considerable financial investments, which publishers are often not inclined to take if there is no guarantee for market success. Even literature works by big names like Borisav Bora Stanković, one of the most famous authors in Serbia at the turn of the nineteenth century and beginning of the twentieth century (whose works were often about Gypsy characters, most prominent among them being the drama Koštana based on the life of Roma from Vranje), needed financial support from the Ministry of Education in the 1920s (AJ-66-638-1059) to fund book purchases of his novel Impure Blood (Petković 1990; Kopah 1982).

It seems that despite the first manuscript's rejection, Simić had continued working on the novel, probably transforming the autobiography into a more fictional story, as an article in the mainstream daily newspaper Vreme from January 1936 states that: "The young Simić has already written a novel full of relief pictures of the Gypsy life, named "Gypsy" because of the fate of its characters. He promises that a novel under this title will appear in bookshops when he leaves the army." (Митровић 1936)

Unfortunately, none of the versions of the manuscript, entitled Gypsy, has been preserved. Simić has also produced a novel or a novelette entitled Gypsy Blood (Циганска 
$к р в$ in Serbian), of which handwritten and typewritten pages have been preserved in Simić's archive (LADA, f. Svetozar Simić). My hypothesis is that this manuscript was also written in the interwar period, probably in the late 193os. Had it been written after the Second World War, it would have contained narratives about the war events as the antifascist movement remembrance was shaping the Yugoslav public memory and was present in many literature works. Also, judging from the preserved pages, the description of the characters, their occupations and way of life refer to the interwar years. However, the possibility that the novel was produced after 1946, but narrated as a story from the interwar years, cannot be completely ruled out.

The main hero in Gypsy Blood is a talented and very young Gypsy musician, Marko, who lives with his family of three generations in a room in Jatagan mahala in Belgrade. Marko, often mocked at and humiliated because of his poverty and drinking, receives a compassionate gesture from Cana (reads as Tsana), a young Roma woman. Marko is haunted by the memory of this gesture and Cana's encouraging attitude towards him. Soon, the young musician becomes part of a famous Gypsy orchestra and is better off. This consequently changes the opinion of the Roma community towards him and mocking transforms into respect. Dragi, also a musician and father of Cana, invites Marko to their home and gets him drunk, after which an engagement is announced despite the reluctance of the young Marko. The preserved pages are only few and we don't know how the story develops, but we can see a motif similar to one of Simić's feuilletons discussed above, "Zira", in which the young journalist is offered a marriage. The life in the poor neighbourhood is picturesquely described in Gypsy Blood:

For Marko it was difficult to drink the first drink, but afterwards many others were offered. Soon a litre was drunk and another one was coming.

Dragi grabbed his contrabass and let his baritone voice sing at will. Full of happiness and joy because Marko is present, Dragi is jubilant because they treat each other well and talk. He is joyful, sings, drinks but the main thing is that Marko is going to be his son-in-law. Whenever he asked Marko if he would become his son-in-law, Marko would say, "I would, I would, but I just need time to mature".

This type of questioning occurred often. He [Dragi] was muttering and asking for a song. Živana started singing like a nightingale in a green meadow. Her song was more intoxicating than the drink. The tense neck vessels were clearly delineated. Dragi belched from the Sevdah song, and with one hand he leaned towards Cana's shoulder, and with the other one - to Marko's shoulder. (ibid.)

The case of Simić's novelistic writings, which have never been published, could be a point of departure for a wider discussion on the novel genre in Romani literature. It has been generally considered and emphasised in analyses and overviews of Romani literature (Eder-Jordan 1993; Romani-Project Graz/Michael Wogg n.d.) that the genre of novel is the least developed, and several explanations were given. The most common reason is the fact that generally this genre is the most elaborated and the last to appear in every literature canon. Since Romani literature was young and recent, thus underdeveloped in terms 
of presentation of all genres, it lacks the most complex genre. This statement somehow hints to the interpretation criticised in the Introduction, that the 'underdevelopment' of Roma community corresponds to the lack of novelists' tradition, usually related to grant narratives of national literature. The case of Simić, however, as well as the case of other novel manuscripts written by Roma that have never been published, to mention only a few, Rudolf Daniel (Zavodska 2016) and Alija Krasnići, point to the need of a more nuanced interpretation that takes into account various publishing infrastructure factors related to the mainstream publishing in general or to the Roma publishing in particular. The most important, regarding the mainstream publishing environment, is that novels are usually the literature pieces that get published very hard due to the largest investment needed. Thus, investing in an unknown and unpublished author is a risky undertaking. In Eastern Europe many novelists are already published writers of other prose genres, before publishing a novel. Additionally, it might also be the lack of experience of Roma writers, who are not always present in professional writers' circles, or are not ready to revise their manuscript following editorial requirements, etc. The examples of published fiction or biographical novels are usually by Roma authors acquainted with the literature circles (Парушев 2006) or focused only on novel writing (Didi 2004, 2008, 2011). The Roma editions are typically supported by either limited donations or by the authors' own funds. Under these circumstances, the authors, who oftentimes fund and self-publish their own works, may prefer to invest in a book product that requires less funding for a greater print run. Presently, the only published fiction novel in (post)Yugoslav territories is, The Sin of a Roma Woman (Greh jedne romkinje in the Serbian original) by Zlatomir Jovanović (2016), issued by a publishing house owner based in Obrenovac, Serbia.

Coming back to Simić, it is clear that he was a very productive prose and polemic texts' writer. Along with his works written during the interwar year (opinion articles, reporting materials, folklore, feuilletons in Romano lil as well as unpublished novels' texts), we should add his unpublished memoir produced probably when he was retired (late 1970s or early 198os). In the manuscript are intertwined narratives about his own life, stories of Roma who Simić has met, folklore motifs, along with opinions and reflections similar to the ones published on the pages of Romano lil. The manuscript is untitled and about $5^{\circ}$ typewritten pages of it are preserved. It is comparable to the messages of the other pieces authored by Simić in the interwar period and can be viewed as quintessence of the author's visions and standpoints:

[T]o be Gypsy, to be mocked and laughed, and whatever happens to scream at you "Gypsy, Gypsy ..." But what have the Gypsies done wrong and why is it like that. Gypsies are not the ones they are thought to be. They are also people as all others. They also have their customs and own life and their ideas about life. They are indeed a particular world, and may be this all looks like that, because they are spread all over the world. However, these are people who one has to feel sorry for, not to chase away, and laugh at as their origins are unknown. Neither where did they come from nor why did they come here and why did they spread all over the world. These are people with their own legends, however without history. 
Our history has been concealed. Our Gypsy life has been disabled. We don't even know why we have been created in this world. Despised and laughed at from the whole world. They despise all Gypsies, me included, although I'm not that typical Gypsy. Let them despise, but I know that Rom-Gypsy is nothing like that. Our old people said that they had heard from their grandfathers that Devla [God in Romani language] - God first created the Gypsy man. Wow, how wonderful was back then on the Earth, how beautiful was the life of Gypsies back then. (LADA, f. Svetozar Simić, Unpublished memoir:69)

The analysis of Simić's unpublished manuscripts shows that all elements and motifs in his novels and essays bear the essence of the narratives for self-representation and a generalisation about the Roma as a collective (suggested by the first person plural pronounce) analysed in the previous subchapter. Namely, they speak about Gypsies/Roma as a whole, and they engage with misunderstanding about the Gypsies and the injustice towards the community throughout history and on an everyday basis. Furthermore, these narratives are self-referential with motifs of the author's own biography, professional and personal experience. They are also embedded with reflections on traditional community narratives about the origins, history and culture of the Roma. The unpublished prose works of Simić should thus be also considered as 'activism' in literary form. Essentially, these works are another means for communicating the goals of the movement for Roma emancipation and achieving equal status with others by creating Romani literature and Roma publications.

Unlike many Roma activists, Simić was a typical prose writer and has not created in the genre of poetry. Interestingly enough, even though Romano lil was created in the tradition of early nationalism - related to poetic writings by intellectuals leading nationalism movement who propagated and communicated the ideas of national emancipation such poetry was not published on the pages of the newspaper. In the other cases of the national Roma emancipation movement and literature development, there are such examples (see, for instance, Romania and USSR). Thus, we should acknowledge that, despite the general pattern of development, we should also take into account the importance of the individual agency and the fact that neither Simić nor the other authors published in Romano lil were inclined to write poetry. The published Roma poetry works in this period were not modern authors' texts but texts of traditional songs that were written down, as were the ones published in the book by Rade Uhlik (1937) and those in "Our songs" rubric of the newspaper.

This rich spectrum of literary and journalistic activities in the main genres of publishing, allows us to identify Svetozar Simić as the founding writer of Romani literature in Yugoslavia and one of the first Roma authors in the novel/novelette genre globally (along for instance with Aleksey Svetlov who authored the novelette Ром Хвасю published in USSR in 1938, see the chapter by Viktor Shapoval in this volume and the original in Светлово 1938). As discussed in the Introduction, according to some studies, the first writer of original Romani literature of Roma origin in this area is Gina Ranjičić. Since the 
identification of Ranjičić as a Roma poetess is a later phenomenon taking place after the 1990s in Yugoslavia, and neither her personality nor her works were in circulation during the interwar period (or even in the socialist period), this phenomenon should not be considered in relation to the Romani literature of interwar Yugoslavia.

Svetozar Simićs writing accomplishments extend also to academic texts and studies, co-authored by Aleksandar Petrović (Петровић \& Симић 1934a, 1934b, 1934c). Simić has also compiled Romani language grammar and Romani vocabulary, the work on which started in the interwar years (Митровић 1936; Николић 1939) and continued during the Second World War when he was a war prisoner in Germany (Acković 2014:263-406). Thus, he is rightfully called the first Roma scholar of Roma background in Yugoslavia (Acković 2014:359; 2020).

\subsection{Conclusion}

The interwar period saw the birth of Roma civic activism and the emergence of the first Roma-initiated publications in the public space in most of the countries of Eastern and South Eastern Europe. The Kingdom of Serbs, Croats and Slovenes (Kingdom of Yugoslavia) was not an exception. The processes of civic emancipation of the Roma community in Yugoslavia manifested itself in different public spheres. Organisations and informal initiatives were set up declaring ambitions for civic and political participation. They were interrelated with activities aiming at differentiation of the Roma on the basis of cultural characteristics considered markers of identity - religion, language, folklore, customs. The Yugoslavian capital was the place where most of these activities took place - the few Roma organisations from that time established and developed activities there, the only Roma-led newspaper Romano lil published there, and the first Yugoslav-wide organisation (Educational Club of the Yugoslav Gypsy Youth) was active for only a couple of months before World War Two.

The youngest and most prominent Yugoslav Roma activist of the time, Svetozar Simić, started publishing the newspaper Romano lil in which various opinion articles about what Roma should do for the prosperity of their own community were published. The topics discussed were important for the Roma community internally and as part of the society as a whole. According to these texts, Roma had to provide schooling for their children, followed by professional training and cultural development. They also had to organise themselves and be engaged with their own community, especially when being more educated. These pleas were directed towards the Roma themselves, who had to awaken and self-organise for the sake of their own community. With this, the newspaper clearly positioned itself as a publishing platform for Roma that communicated the up-to-date visions of the Roma activism of the period. Romano lil was thus publicly sharing the messages of the Roma activists, present in the public space in the interwar period, known also 
through the activities of the several Roma-led organisations and grass-root initiatives, occasionally reported in mainstream media (Marushiakova and Popov 2021a:180-235).

At the same time, Romano lil addressed the broader audience and exemplified the society-community juxtaposition in various ways. On the one hand, it communicated the inseparability of the Roma as part of all Yugoslav communities and as part of the Serbian nation. On the other hand, although created and published primarily for Roma and giving platform to their visions, the content of the periodical clearly addressed a broader non-Roma readership, present with the collective expressions 'our Serbian brothers' or gadže. The newspaper was also published primarily in Serbian and always provided translations in Serbian when Romani texts appeared. The representation of the Roma community as a people united by a common identity and the vision for their further advancement were shared and promoted among their co-nationals (Roma and non-Roma alike). Romano lil thus served as means for negotiating Roma positionality and gaining collective recognition.

Simić has also written other works that have not been published but embedded in literature form similar narratives about the Roma that represented them as a collective, while strengthening their identity and achieving a status equal to all other communities (through identification and differentiation). They have the same motifs and keynote messages like the published texts produced by Simic during the interwar period and, later, in socialist Yugoslavia, communicating the same ideas in a longer and more complex literature form, one which united folklore presentation, different contemporary character stories, memoirs and essay-style opinion paragraphs.

In this respect, both the newspaper publications and all other literature texts authored by Simić, preserved in manuscript form, seem to be strategically thought out in terms of content and way of narrating, with the aim of creating a narrative about the Gypsies as a people united by a common culture and history, thus equal to the other people of the Kingdom of Yugoslavia. An important component of the newspaper's content was the emphasis on Roma belonging to the nation and sharing its history. Examining the essence of the messages that the newspaper conveys to both Roma and a non-Roma audience - that Roma are one community with their own rich culture and history, the need for Roma to be more engaged and self-organise as a community, the need for education and professional training as a key for a better future, the fight against majority misconceptions about the Gypsies - we see the main point for Roma emancipation that continued to shape the narratives of Roma activism in texts and activities in later periods up to the present. Although limited, in terms of production and authors, the writing activities of the Roma elite in interwar Yugoslavia have been firmly tied with the visions of the Yugoslav Roma civil activism. Writing and publishing was a means for projection and extension in the public field of this activism. This means it was a common channel for public expression and, not only the content of the publications, but the writing and publishing activities per se were a signal that Roma activists-writers were aiming to present the community as a collective. 